\title{
Growth rates of Antarctic marine phytoplankton in the Weddell Sea*
}

\author{
Annette Spies** \\ Alfred-Wegener-Institute for Polar and Marine Research, D-2850 Bremerhaven, Federal Republic of Germany
}

\begin{abstract}
Natural microplankton from summer surface waters of the Weddell Sea was incubated in $10 \mathrm{l} \mathrm{Nalgene} e^{\$ 0}$ flasks at $-1{ }^{\circ} \mathrm{C}$ and irradiance $45 \mu$ Einst $\mathrm{m}^{-2} \mathrm{~s}^{-1}$. Ambient nutrient concentrations were high enough to support rapid biomass accumulation. Maximum growth rates and generation times of the dominant diatom assemblages were determined by successive cell counts. Growth rates ranged from 0.38 to 1.33 divisions $\mathrm{d}^{-1}$ and generation times varied from 18.0 to $63.2 \mathrm{~h}$ division ${ }^{-1}$. Thus, rapid growth at low temperatures is possible; growth rates of Weddell Sea phytoplankton are comparable to those of temperate latitudes.
\end{abstract}

\section{INTRODUCTION}

After several decades of biological research in the Southern Ocean, we still lack conclusive data to support the traditional view of the biological richness of the waters (Hart 1934). On the contrary, extensive biomass studies and productivity measurements in the 60 's and 70's produced values which were more comparable to those of oligotrophic seas (e.g. Walsh 1969, El-Sayed \& Turner 1977). A variety of factors have been considered as rate-limiting for Antarctic phytoplankton growth e.g. light, turbulence, temperature, silicate (e.g. El-Sayed \& Mandelli 1965, Neori \& Holm-Hansen 1982, Jacques 1983). Very little is known about the metabolic activities of Antarctic phytoplankton, and whether or not they are well adapted to their environment is still a matter of controversy (El-Sayed 1984). Based on the results of their physiological experiments, Tilzer \& Dubinsky (1987) conclude that under the nutrient-saturated conditions of the Southern Ocean the temperature dependence of both photosynthesis and algal respiration is a key factor in controlling phytoplankton productivity. On the other hand, the apparent high productivity of the krill population is strongly suggestive of a productive phytoplankton (Priddle et al.

- Contribution No. 59 of the Alfred-Wegener-Institute for Polar and Marine Research

- Present address: Institut für Biochemie und Lebensmittelchemie, Universität Hamburg, D-2000 Hamburg 13, F. R. Germany
1986). A wide range of cell division rates have been recorded (e.g. Holm-Hansen et al. 1977, El-Sayed \& Taguchi 1981, Miller et al. 1985); most of these data are estimates of growth rates based on radiotracer studies and phytoplankton biomass measurements. The highest recorded growth rates together with reports of extensive blooms (El-Sayed 1970, Smith \& Nelson 1985) suggest that rapid growth is possible at in situ temperatures.

The objective of this study was to determine whether phytoplankton cells from the Weddell Sea are adapted to their cold environment, so that growth rates are high in spite of low temperatures. For this purpose, the natural microplankton from surface waters was incubated in experimental containers on board the RV Polarstern. The approach allows accurate estimates of growth rates of individual phytoplankton groups or species under approximate field conditions of temperature, salinity and nutrient concentrations.

\section{MATERIAL AND METHODS}

All sampling and growth experiments were conducted during Cruise ANT III/3 on RV Polarstern in the austral summer (4 to 27 Feb) of 1985 . Station locations are shown in Fig. 1; the experiments are indexed by 'CON' (container) plus the station number. Seawater was collected from the sea surface (bucket) and immediately dispensed into acid-rinsed Nalgene ${ }^{\text {B }}$ polycarbonate flasks (10 I volume); the water was not 
prescreened for zooplankton, nor received any additives. Replicate experiments were run at all stations (except 348). The flasks were incubated at $-1{ }^{\circ} \mathrm{C}$ in a controlled-environment laboratory container on board. An irradiance of $45 \mu$ Einst $\mathrm{m}^{-2} \mathrm{~s}^{-1}$ was provided by daylight fluorescent tubes. All experiments were performed under continuous light. The flasks were sampled at regular intervals ( 1 to $3 \mathrm{~d}$ ) for pigments, inorganic nutrients, and species analysis. The experiments were terminated when autotrophic biomass reached a maximum and nitrate concentrations were exhausted. Pigment and nutrient samples were analysed within hours.

Pigment extraction followed the procedure given by Evans \& O'Reilly (1982). Chlorophyll $a$ and phaeophytin a were determined fluorometrically with a calibrated (chlorophyll standard) Turner Designs fluorometer. Samples for nutrients (nitrate and nitrite, ammonium, phosphate and silicate) were determined as described by Grasshoff (1976). For species analysis of phytoplankton, 50 to $100 \mathrm{ml}$ seawater samples were preserved with Lugol's solution. Quantitative counting and identification was done ashore according to the Utermöhl (1958) method. The relative abundance of species in a sample is based on quantitative counts or was calculated after counting at least 400 cells in 4 subsamples. Quantitative counts of phytoplankton sur- face samples in the field were performed by Qingbo Sui (Institut für Meereskunde, Universität Kiel, FRG). The growth constant $(\mathrm{k})$ of the dominant diatoms was determined from successive counts during the exponential growth phase of the batch cultures; the value of $k$ was estimated graphically from a semi-log plot and computated by using the formula of Guillard (1973)

$$
\mathrm{k}\left(\text { division } \mathrm{d}^{-1}\right)=\log \left(\mathrm{N}_{1} / \mathrm{N}_{0}\right)(3.322 / \mathrm{t})
$$

where $N_{1}$ and $N_{0}=$ cell concentrations at the end and beginning of a time interval ( $\mathrm{t}$ ).

Knowing $k$, the generation time $\left(\mathrm{T}_{\mathrm{d}}\right)$ is:

$$
\mathrm{T}_{\mathrm{d}}\left(\mathrm{h}_{\text {division }}{ }^{-1}\right)=\frac{24}{\mathrm{k}}
$$

The growth constant represents the maximal growth rate for that diatom population determined under that one set of conditions of light and temperature, nutrients and species composition.

Hydrographic and environmental data were collected with a Neil Brown CTD-Rosette sampler by a group of physical oceanographers from the AlfredWegener-Institut, the Scripps Institution of Oceanography, La Jolla, and the Institut für Umweltphysik der Universität Heidelberg. $H$. Hellmer kindly provided hydrographic profiles for the stations from which the depth of mixing $\left(\mathrm{z}_{\mathrm{m}}\right)$ was estimated.

Fig. 1. Location of experimental stations in the southern and southeastern Weddell Sea during the RV Polarstern cruise ANT III/3, 1985

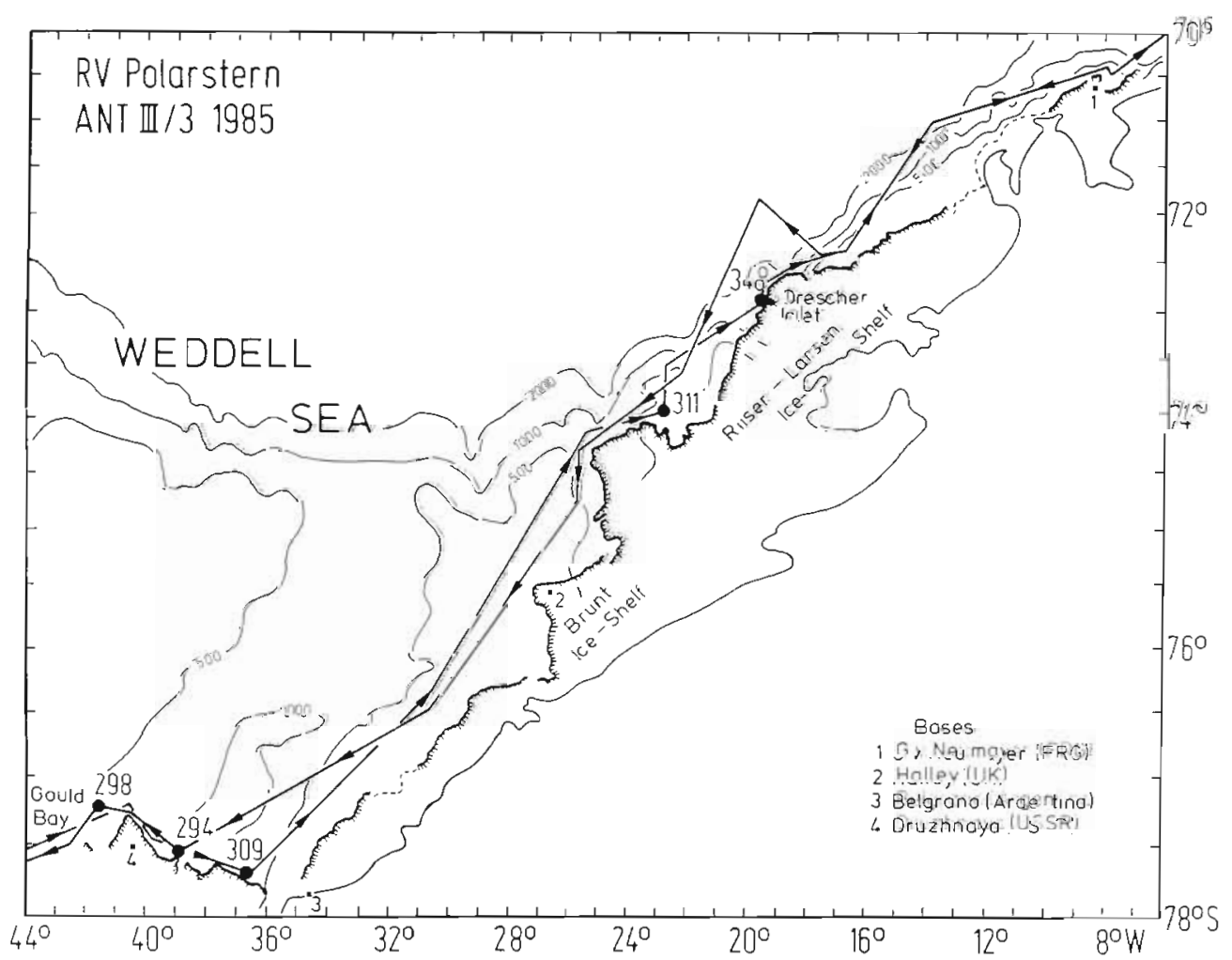




\section{RESULTS}

The growth experiments were performed in different areas of the Weddell Sea. Regional differences in hydrographical, biological, and chemical conditions are listed in Table 1. During the expedition, pack ice cover in the Weddell Sea varied between $1 / 10$ and $9 / 10$; the recorded lower surface salinities originated from melting pack ice. In general, biomass concentrations were low (except Stn 348) and nutrient concentrations were high at all stations. While the latter values differed regionally, nutrient ratios, especially Si:N and $\mathrm{N}$ :P ratios, showed little variation. N:P ratios were close to the Redfield Ratio indicating ideal growth conditions as far as macro-nutrients were concerned.
In February 1985, the microplankton in the Weddell Sea surface waters was composed of small and large flagellates (mainly dinoflagellates and Distephanus speculum), heterotrophic protozoa, and a diatom assemblage of great diversity. The majority (Cup to $>90 \%$ ) of the flagellates belonged to the nanoplankton size fraction; cells measured 3 to $6 \mu \mathrm{m}$ in diameter. Diatom abundance (by numbers) varied between $1.5 \%$ at $\operatorname{Stn} 309$ and $37.7 \%$ at $\operatorname{Stn} 294$. Due to their relatively large cell size, the diatom contribution to total biomass was much larger than their cell numbers suggested. At the station with the highest chlorophyll a concentration (Stn 348 ) diatoms accounted for $22.6 \%$ of the total cell numbers. In Table 2 , the diatom assemblages of the laboratory blooms and in the field are compared; most

Table 1. Initital environmental conditions and nutrient ratios for growth experiments. $z_{m}$ : depth of mixed layer

\begin{tabular}{|c|c|c|c|c|c|c|c|c|c|c|c|c|c|}
\hline \multirow{2}{*}{$\begin{array}{l}\text { Date } \\
(1985)\end{array}$} & \multirow[t]{2}{*}{ Stn } & \multirow[t]{2}{*}{ Location } & \multirow{2}{*}{$\begin{array}{c}\mathrm{T} \\
\left({ }^{\circ} \mathrm{C}\right)\end{array}$} & \multirow{2}{*}{$\begin{array}{c}S \\
(\%)\end{array}$} & \multirow{2}{*}{$\begin{array}{l}z_{m} \\
(\mathrm{~m})\end{array}$} & \multirow{2}{*}{$\begin{array}{c}\text { Biomass } \\
\left(\mathrm{Chl} a ; \mathrm{mg} \mathrm{m}^{-3}\right)\end{array}$} & \multicolumn{4}{|c|}{ Nutrients (mg-at $\mathrm{m}^{-3}$ ) } & \multicolumn{3}{|c|}{ Nutrient ratios } \\
\hline & & & & & & & $\mathrm{NO}_{3}^{-}+\mathrm{NO}_{2}^{-}$ & $\mathrm{NH}_{4}^{+}$ & $\mathrm{PO}_{4}^{3-}$ & $\mathrm{SiO}_{4}^{-}$ & Si:N & Si:P & $N: P$ \\
\hline & & ould Bay/Weddell S & & & & & & & & & & & \\
\hline $04 \mathrm{Feb}$ & 294 & $77^{\circ} 34^{\prime} \mathrm{S} 38^{\circ} 52^{\prime} \mathrm{W}$ & -1.1 & 33.85 & 45 & 1.17 & 16.88 & 0.44 & 1.18 & 44.12 & 2.5 & 37.4 & 14.7 \\
\hline 05 Feb & 298 & $77^{\circ} 14^{\prime} \mathrm{S} 41^{\circ} 32^{\prime} \mathrm{W}$ & -1.2 & 34.35 & 30 & 1.20 & 20.11 & 0.60 & 1.44 & 48.82 & 2.4 & 33.9 & 14.4 \\
\hline 09 Feb & 309 & $77^{\circ} 44^{\prime} \mathrm{S} 36^{\circ} 26^{\prime} \mathrm{W}$ & -1.4 & 33.00 & 20 & 0.98 & 22.02 & 0.20 & 1.68 & 66.60 & 2.8 & 40.5 & 14.5 \\
\hline & & SE Weddell Sea & & & & & & & & & & & \\
\hline $11 \mathrm{Feb}$ & 311 & $73^{\circ} 55^{\prime} \mathrm{S} 22^{\circ} 48^{\prime} \mathrm{W}$ & -0.3 & 34.60 & 55 & 0.87 & 15.52 & 0.63 & 1.15 & 56.10 & 3.5 & 48.8 & 14.0 \\
\hline $20 \mathrm{Feb}$ & 348 & $72^{\circ} 56^{\prime} \mathrm{S} 19^{\circ} 10^{\prime} \mathrm{W}$ & -1.3 & 33.99 & 18 & 3.14 & 15.76 & 1.36 & 0.95 & 47.02 & 2.7 & 49.5 & 18.0 \\
\hline
\end{tabular}

Table 2. Composition of the diatom assemblages of genera in experimental containers (CON) and in surface waters at the different sampling stations ( $\mathrm{Stn}$ ). Abundances are based on quantitative microplankton cell counts (flagellates included). The experimental data represent percentages at the $\mathrm{Chl}$ a maximum in the batch cultures; mean values of replicate containers are given $\pm 1 \mathrm{SD}$; field data are presented in symbols; each asterisk represents an order of magnitude in real numbers

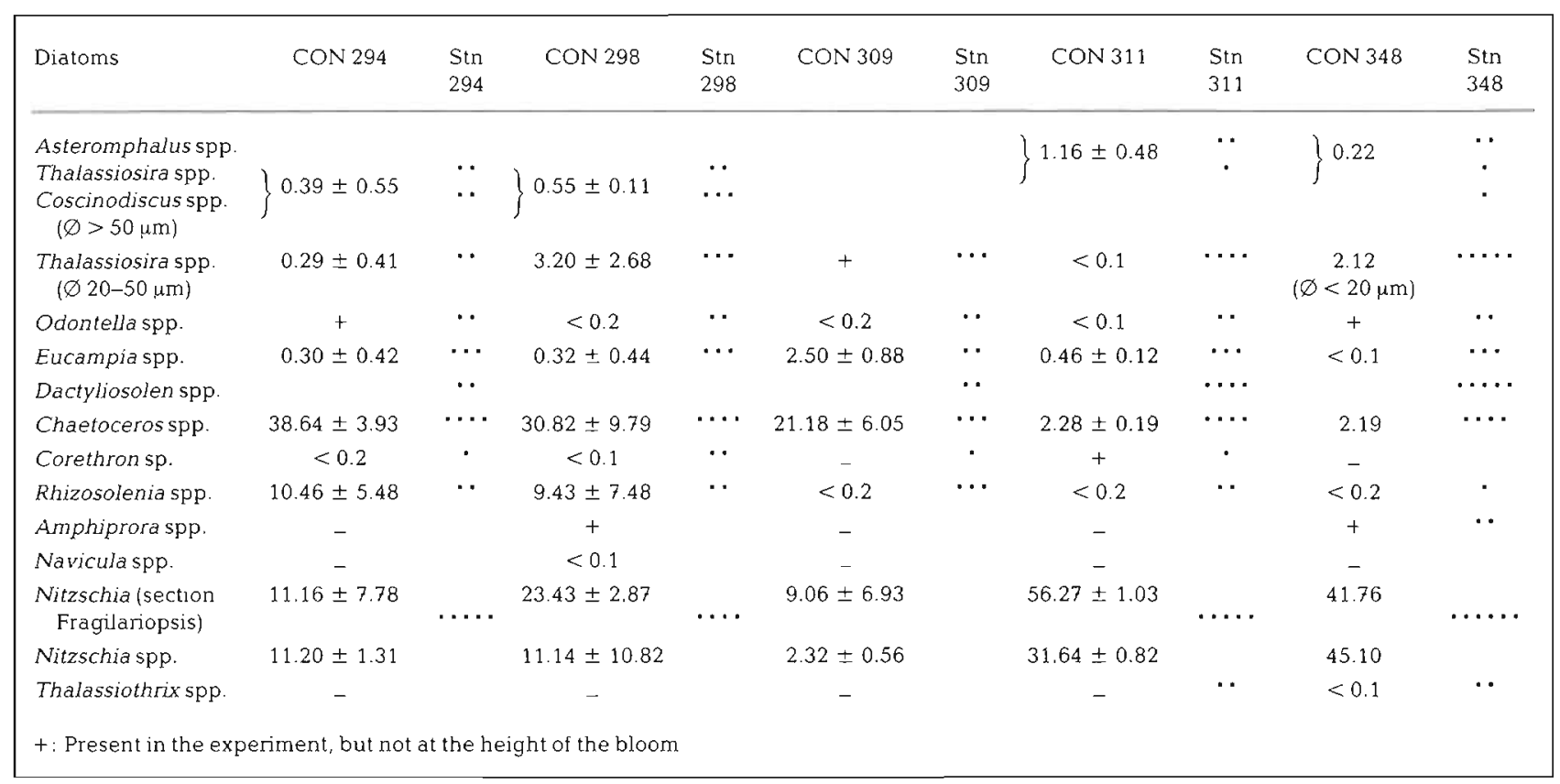




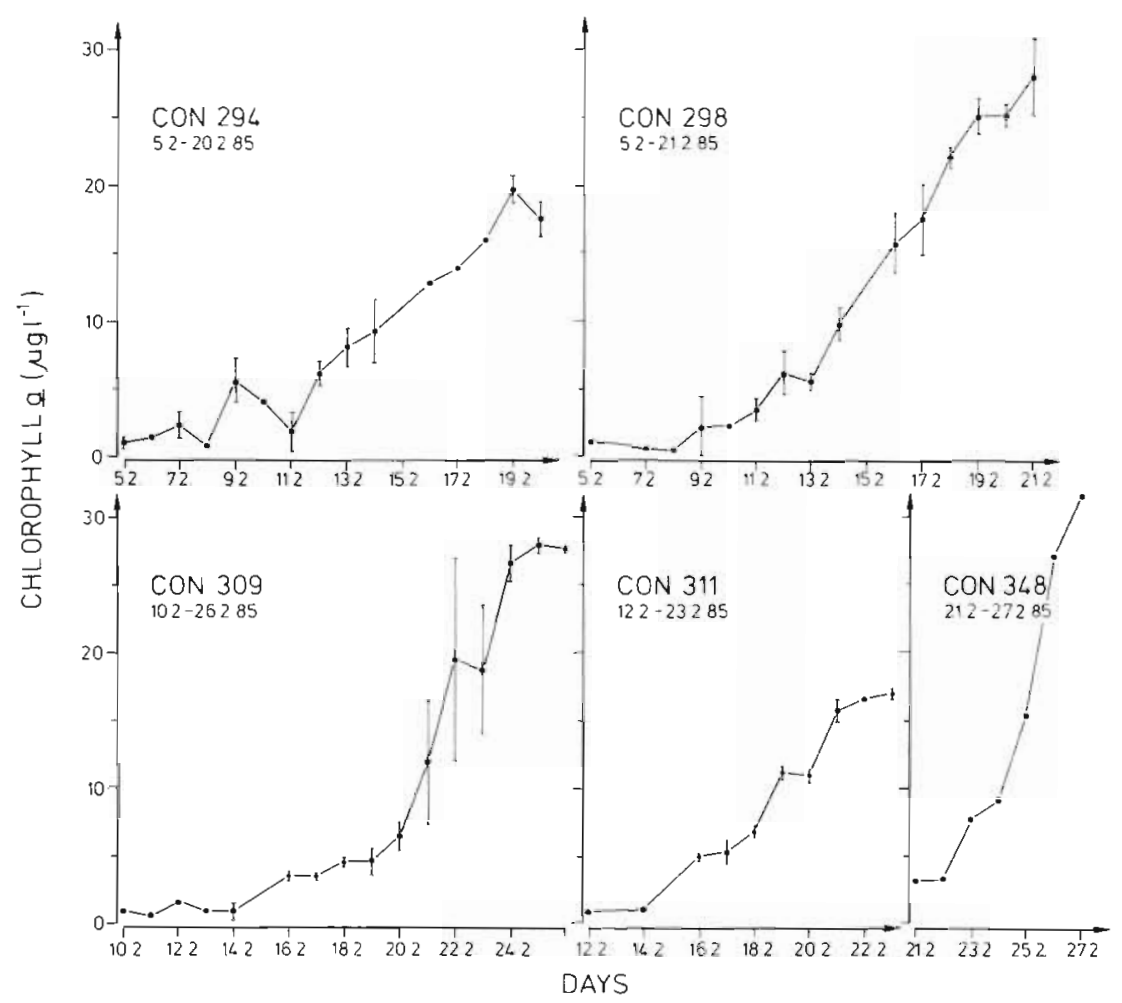

Fig. 2. Chlorophyll a concentrations during the growth experiments. Mean values of replicate experiments are shown $\pm 1 \mathrm{SD}$, when $1 \mathrm{SD}>0.2 \mu \mathrm{g} \mathrm{l}^{-1}$ (except CON 348) of the species found in the field were present and grew in the laboratory. In the surface waters of the southern Weddell Sea, centric diatoms were most abundant, whereas at Stns 311 and 348 further to the north in the SE Weddell Sea, pennate diatoms outnumbered the former. The same pattern was found in the laboratory. Very small Nitzschia cylindrus (section Fragilariopsis) were present at Stns 311 and 348 and showed weedlike growth in all experimental containers, just before the experiments were terminated; they were not enumerated.

In the experimental containers, growth started after a short lag-phase (Fig. 2). Since initial biomass and nutrient concentrations, as well as the dominant diatom groups, differed between stations, final maximum chlorophyll a values were significantly different between treatments. The peak in biomass accumulation coincided with nitrogen $\left(\mathrm{NO}_{3}^{-}+\mathrm{NO}_{2}^{-}\right)$exhaustion (Fig. 3); concurrently, phosphate concentrations declined; in Containers 294 and 298 levels were below the detection limit before nitrogen was completely taken up. Silica was never exhausted (Fig. 3).

Growth curves of the dominant diatoms from the Weddell Sea are shown in Fig. 4. The average exponential growth rates and generation times are listed in Table 3. Maximum growth rates of the different diatom groups did not always coincide with the maximum increase in biomass. In the course of the experiments, a diatom succession was observed. Small species reached their maximum in abundance before the general biomass peak, whereas highest growth rates for large diatom species were measured just before or together with nitrogen exhaustion. The dominant groups at the height of the laboratory blooms were those diatom groups which were most abundant in the field and grew fastest in the experimental containers (Tables $2 \& 3$ ).

\section{DISCUSSION}

The specific growth rate of phytoplankton is an important parameter in evaluating species distribution and in estimating turnover rates of organic matter in aquatic ecosystems (Malone 1982). However, there is no dependable method for estimating phytoplankton growth or division rate in the natural environment (Laws et al. 1984). The conversion of ${ }^{14} \mathrm{C}$ uptake rates into carbon-specific growth is associated with uncertainties in estimating algal biomass as carbon (Banse 1977). In addition, the relationship between short-term variations in photosynthesis and daily growth is poorly understood. For example, photosynthesis is more variable than division rate and varies on time scales shorter than a generation time as a consequence of diel rhythms and environmental effects (Malone 1982) Keeping this in mind, the ongoing controversy as to whether or not Antarctic phytoplankton is well adapted to its environment is rather a matter of experimental 


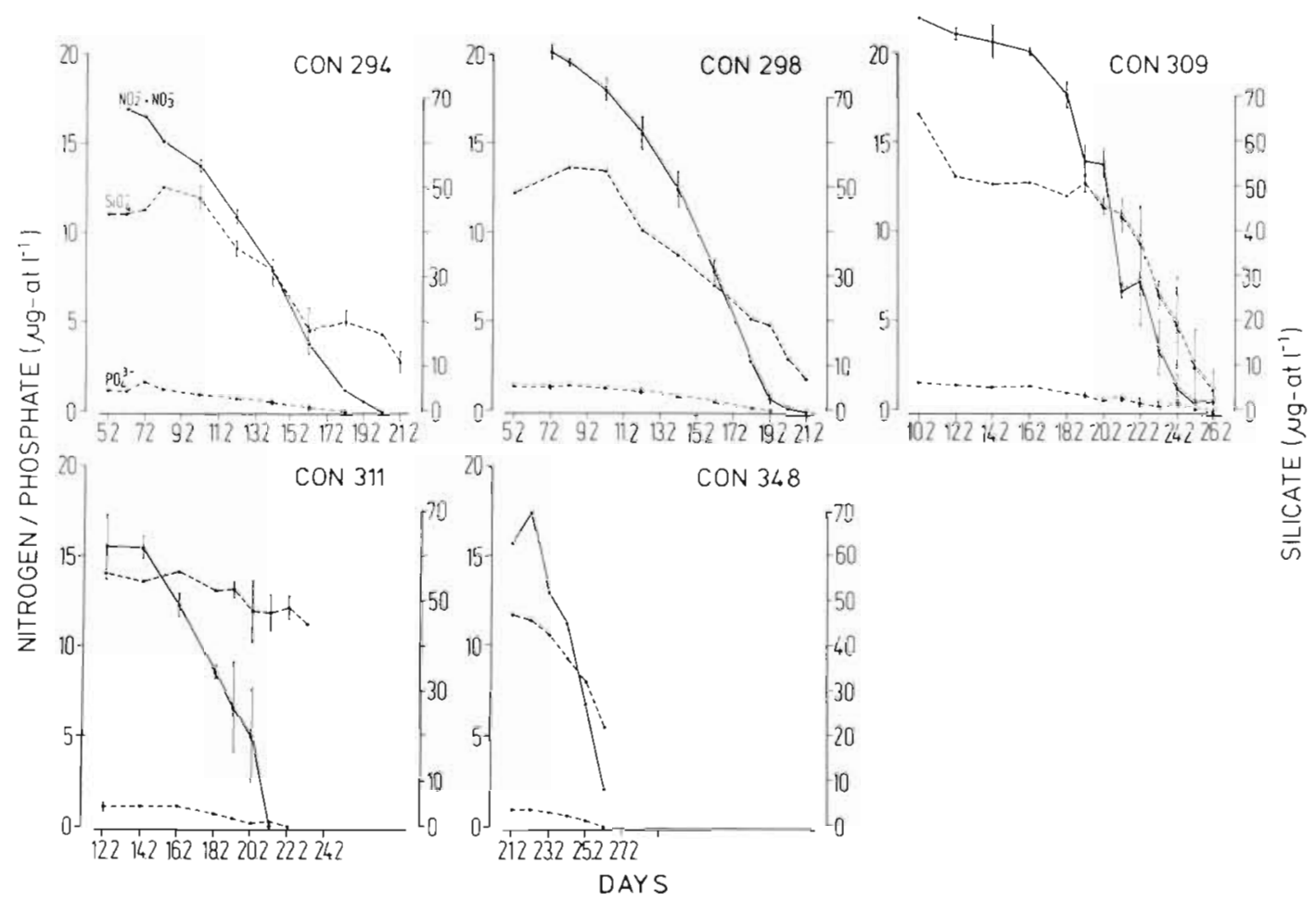

Fig. 3. Nitrogen (nitrate + nitrite), phosphate and silicate concentrations during the growth experiments, shown $\pm 1 \mathrm{SD}$, when $1 \mathrm{SD}>0.1 \mathrm{\mu g} \mathrm{l}^{-1}$ (nitrate + nitrite, phosphate), or $>0.5 \mu \mathrm{g} \mathrm{I}^{-1}$ (silicate) (except CON 348 )

approach and conditions than a major issue in the context of Antarctic primary production.

All in vitro techniques suffer from shortcomings, such as the lack of natural turbulence, wall effects and the artificial light regime. Some of the limitations can be neglected here because of the short duration of the experiments. The experimental approach, however, made it possible to grow natural Antarctic microplankton at in situ temperatures, natural nutrient concentrations and a controlled low irradiance light regime. In this study, growth rates of relatively large diatoms from surface waters were determined. Due to their cell size they contribute substantially to the overall biomass in the euphotic zone, and they are known to form extensive blooms (El-Sayed 1971, El-Sayed \& Weber 1982). The surface flora was a good representation of the phytoplankton assemblage in the euphotic zone despite considerable variation in the numerical abundance of certain genera (Qingbo Sui, Institut für Meereskunde, Universität Kiel, FRG, pers. comm.).

Among other variables the maximum growth rate of microalgae is correlated with cell size; in general, smaller algae grow faster than larger ones (Geider et al. 1986). Thus, the growth rate estimates of the relatively large diatoms which were present in the field and in the experimental containers were probably less than the growth rates of the pico- and nanoplankton cells (e.g. Nitzschia cylindrus). The growth rates of the nanoplankton are difficult to assess in the same experimental design, because the consumers of this size fraction (e.g. tintinnids, heterotrophic flagellates) belong to the microplankton, the same size class as the large diatoms. On the other hand, pico- and nanoplankton represent a considerable fraction of the natural Weddell Sea plankton (von Bröckel 1981, 1985, ElSayed \& Taguchi 1981, this study); further experiments are necessary in order to evaluate their growth dynamics. The experiments presented here confirm earlier suggestions that Antarctic diatoms are very well adapted to the environmental conditions (Priddle et al. 1986). Growth rates, obtained from the container experiments, for Weddell Sea diatoms are comparable to values observed in the Bering Sea (Saino \& Hattori 1977) and in the Canadian Arctic (Harrison et al. 1982. Hsiao 1985). They also fall within the range observed in the euphotic zone of waters in temperate and tropical oceans (Parsons et al. 1977, Goldman et al. 1979).

Usually, nutrients are considered unlikely to be a limiting factor for primary production in the Southern Ocean (Hayes et al. 1984). In 2 experiments (CON 294 and CON 298), phosphate concentrations dropped below the detection limit before nitrogen was exhausted. Further experiments will be necessary to test whether phosphate can become limiting under 

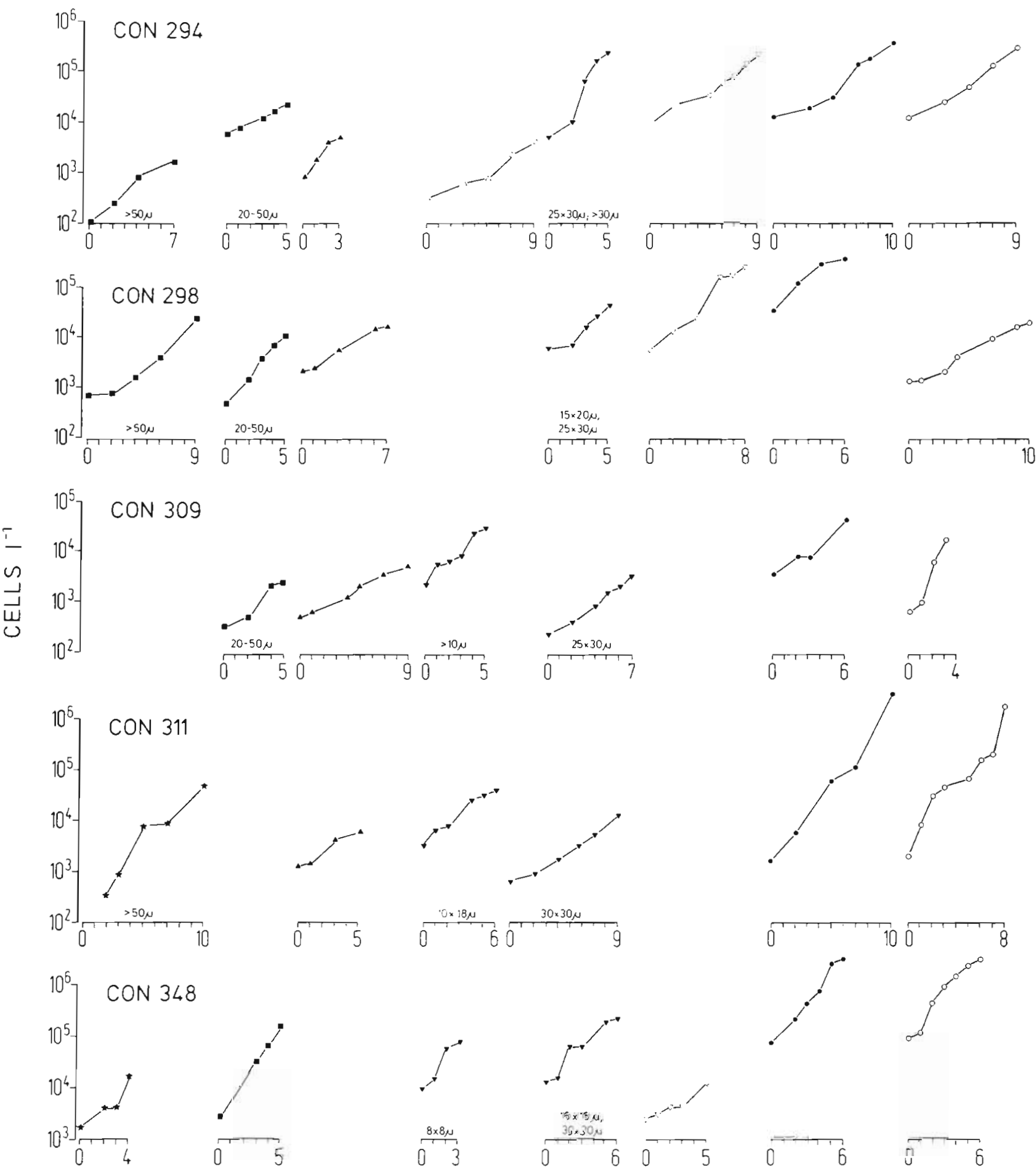

- Thaiossiosira spp

- Eucampia spo

- Chaeloceros spo

- Rnizosolenia spo

- Niźscha spo Is Fiagriariopsisl

- Asteramphalus spe

Adontella spp

Ditzschio spo

Fig. 4. Growth curves of dominant diatom groups of Antarctic marine phytoplankton in the Weddell Sea. Period of exponential growth and sampling frequency is indicated 
Table 3. Average maximum growth rates ( $k$; division $\mathrm{d}^{-1}$ ) and generation times ( $T_{\mathrm{d}}$; $\mathrm{h}_{\mathrm{division}}{ }^{-1}$ ) of $\mathrm{natural}$ Antarctic marine diatoms under approximate field conditions of temperature, salinity and nutrient concentrations in experimental containers

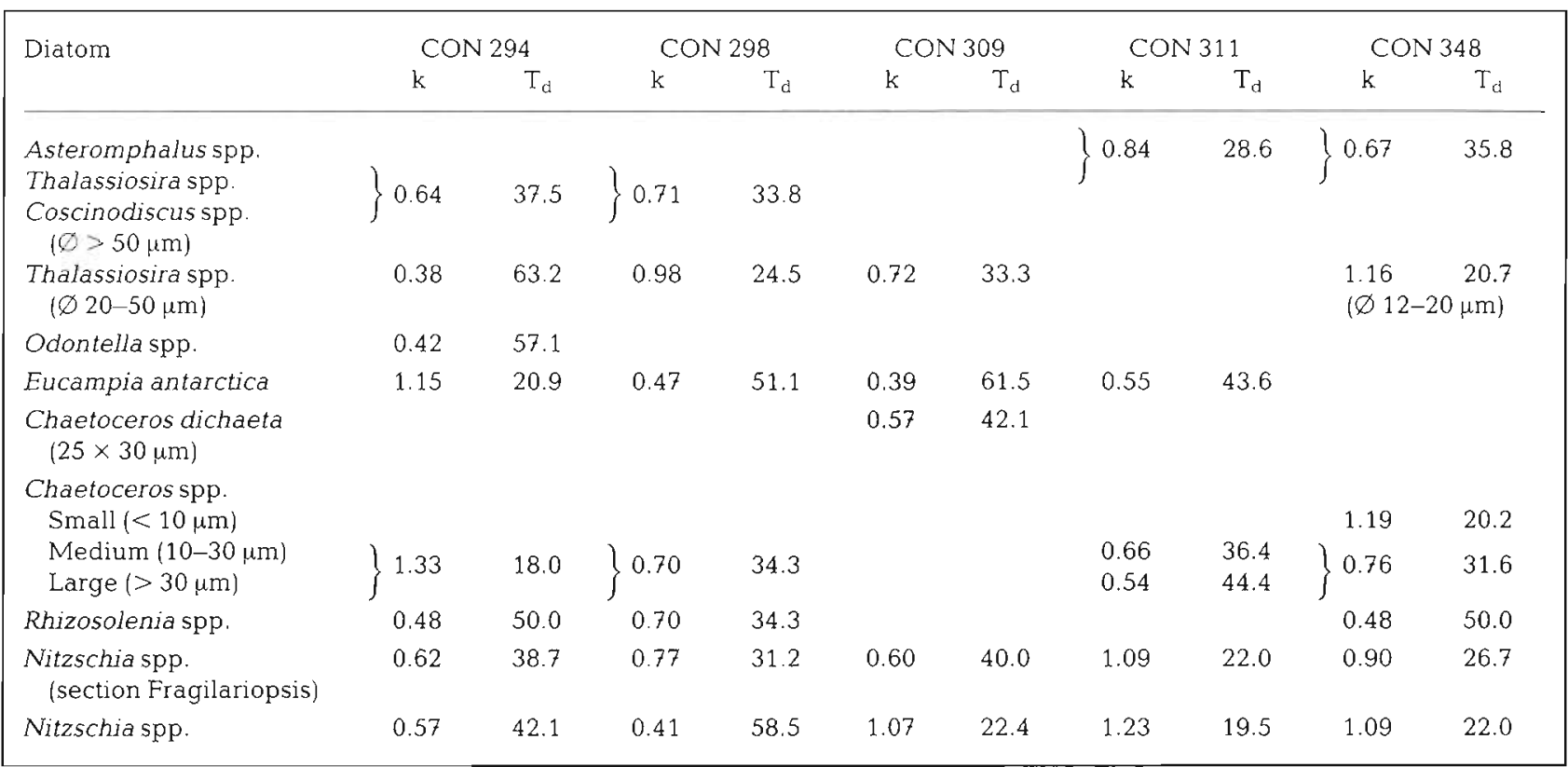

certain bloom conditions when temperatures are low. In other marine ecosystems, phosphate regeneration is considered to be very fast.

In the short summer season, the near shelf-ice areas of the Weddell Sea are characterized by a stable 20 to $55 \mathrm{~m}$ deep surface layer, and only strong storms may erode the pycnocline. Thus, during the main growing season, the depth of vertical mixing is considerably reduced. An apparent seasonal progression of maximum primary production southward was indicated by a larger proportion of diatoms at the most southern stations and in Drescher Inlet, whereas small heterotrophic flagellates, dinoflagellates, silicoflagellates and protozoa were characteristic of stations further to the north.

Growth characteristics, rates and generation times of the Weddell Sea diatoms will vary from month to month and probably from year to year with species composition, mixing depth and other environmental parameters. The present study shows that high growth rates are possible at very low temperatures and relatively low irradiance. This confirms that Antarctic algae are well adapted to their cold environment and that factors other than temperature control Antarctic phytoplankton growth.

Acknowledgements. My thanks to Dr W. Stöffler, A. Meiners and $P$. Fritsche who kindly assisted in the field sampling programme and the laboratory analyses, to my colleagues for their constructive criticism, to G. Dansauer for preparing the graphs, and to $\mathrm{S}$. Marschall for typing the manuscript.

\section{LITERATURE CITED}

Banse, K. (1977). Determining the carbon to chlorophyll ratio of natural phytoplankton. Mar. Biol. 41: 199-212

Brökel, K. von (1981). The importance of nanoplankton within the Antarctic ecosystem. Kieler Meeresforsch., Sonderh. 5: 61-67

Brökel, K. von (1985). Primary production data from the south-eastern Weddell Sea. Polar Biol. 4: 75-80

El-Sayed, S. Z. (1970). On the productivity of the Southern Ocean. In: Holdgate, M. W. (ed.) Antarctic ecology, Vol. 1. Academic Press, London, p. 119-135

El-Sayed, S. Z. (1971). Observations on phytoplankton bloom in the Weddell Sea. In: Llano, G. A., Wallen, I. E. (ed.) Biology of the Antarctic Seas IV. American Geophysical Union, Washington, D. C., p. 301-312

El-Sayed, S. Z. (1984). Productivity of the Antarctic waters - a reappraisal. In: Holm-Hansen, O., Bolis, L., Gilles, R, (ed.) Marine phytoplankton and productivity. Lecture notes on coastal and estuarine studies, Vol. 8. Springer-Verlag. Berlin, p. 19-34

El-Sayed, S. Z., Mandelli, E. F. (1965). Primary production and standing crop of phytoplankton in the Weddell Sea and Drake Passage. In: Llano, G. (ed.) Biology of the Antarctic Seas II. American Geophysical Union, Washington, D. C., p. $87-106$

El-Sayed, S. Z., Turner, J. T. (1977). Productivity of the Antarctic and tropical/subtropical regions: a comparative study. In: Dunbar, M. J. (ed.) Polar oceans. Arctic Institute of North America, Calgary, Alberta, p. 463-503

El-Sayed, S. Z., Taguchi, S. (1981). Primary production and standing crop of phytoplankton along the ice-edge in the Weddell Sea. Deep Sea Res. 28A: 1017-1032

El-Sayed, S. Z., Weber, L. H. (1982). Spatial and temporal variations in phytoplankton biomass and primary productivity in the southwest Atlantic and Scotia Sea. Polar Biol. 1: $83-90$

Evans, C. A., O'Reilly, J. E. (1982). A handbook for the meas- 
urement of chlorophyll $a$ in netplankton and nannoplankton. SCAR/SCOR/IABO/ACHRR Group of specialists on living resources of the southern oceans. NOAA Publ. USA, p. $1-44$

Geider, R. J., Platt, T., Raven, J. A. (1986). Size dependence of growth and photosynthesis in diatoms: a synthesis. Mar. Ecol. Prog. Ser 30: 93-104

Goldman, J. C., McCarthy, J. J., Peavy, D. G. (1979). Growth rate influence on the chemical composition of phytoplankton in oceanic waters. Nature, Lond. 279: 210-215

Grasshoff, K. (1976). Methods of seawater analysis. Verlag Chemie, Weinheim

Guillard, R. R. L. (1973). Division rates. In: Stein, J. R. (ed.) Handbook of phycological methods: culture methods and growth measurements. University Press, Cambridge, p. $289-320$

Harrison, W. G., Platt, T., Irwin, B. (1982). Primary production and nutrient assimilation by natural phytoplankton populations of the eastern Canadian Arctic. Can. J. Fish. Aquat. Sci. 39: 335-345

Hart, T. J. (1934). On the phytoplankton of the south-west Atlantic and the Bellingshausen Sea. 'Discovery' Rep. 8: $1-268$

Hayes, P. K., Whitaker, T. M., Fogg, G. E. (1984). The distribution and nutrient status of phytoplankton in the Southern Ocean between $20^{\circ}$ and $70^{\circ} \mathrm{W}$. Polar Biol. 3: 153-165

Holm-Hansen, O., El-Sayed, S. Z., Franceschini, G. A., Cuhel, R. L. (1977). Primary production and the factors controlling phytoplankton growth in the Southern Ocean. In: Llano, G. A. (ed.) Adaptations within Antarctic ecosystems. Smithson. Inst., Washington, D. C., p. 11-50

Hsiao, S. I. C. (1985). The growth of Arctic marine phytoplankton in Frobisher Bay. Arctic 38: 31-38

Jacques, G. (1983). Some ecophysiological aspects of the Antarctic phytoplankton. Polar Biol. 2: 27-33

Laws, E. A., Redalje, D. G., Haas, L. W., Bienfang, P. K., Eppley, R. W., Harrison, W. G., Karl, D. M., Marra, J.
(1984). High phytoplankton growth and production rates in oligotrophic Hawaiian coastal waters. Limnol. Oceanogr 29: 1161-1169

Malone, T C. (1982). Phytoplankton photosynthesis and carbon-specific growth: light-saturated rates in a nutrientrich environment. Limnol. Oceanogr. 27: 226-235

Miller, D. G. M., Hampton, I., Henry, J., Abrams, R. W., Cooper, J. (1985). The relationship between krill food requirements and phytoplankton production in a sector of the southern Indian Ocean. In: Siegfried, W. R., Condy, P. R., Laws, R. M. (ed.) Antarctic nutrient cycles and food webs. Springer-Verlag, Berlin, p. 362-371

Neori, A., Holm-Hansen, O. (1982). Effect of temperature on rate of photosynthesis in Antarctic phytoplankton. Polar Biol. 1: 33-38

Parsons, T. R., Takahashi, M., Hargrave, B. (1977). Biological oceanographic processes, 2nd edn. Pergamon Press, Oxford

Priddle, J., Hawes, I., Ellis-Evans, J. C. (1986). Antarctic aquatic ecosystems as habitats for phytoplankton. Biol. Rev. 61 $199-238$

Saino, T., Hattori, A. (1977). Estimate of the growth rate of phytoplankton in the surface waters of the Bering Sea and the northern North Pacific. Mar. Sci. Communs 3: 1-19

Smith, W. O., Nelson, D. M. (1985). Phytoplankton bloom produced by a receding ice edge in the Ross Sea: spatial coherence with the density field. Science 227: 163-166

Tilzer, M. M., Dubinsky, Z. (1987). Effects of temperature and day length on the mass balance of Antarctic phytoplankton. Polar Biol. 7: 35-42

Utermöhl, H. (1958). Zur Vervollkommnung der quantitativen Phytoplankton-Methodik. Mitt. int. Verein. theor. angew. Limnol. 9: 1-39

Walsh, J. J. (1969). Vertical distribution of Antarctic phytoplankton. II. A comparison of phytoplankton standing crops in the Southern Ocean with that of the Florida Strait. Limnol. Oceanogr. 14: 86-94 